\title{
PENGARUH MODEL INKUIRI BERBANTUAN ALAT PERAGA EDUKATIF TERHADAP LITERASI SPASIAL
}

\author{
Via Yustitia \\ Universitas PGRI Adi Buana Surabaya \\ via.yustitia@unipasby.ac.id
}

\begin{abstract}
Abstrak
Literasi spasial berhubungan dengan kemampuan menggunakan matematika yang berhubungan dengan geometri. Calon guru sekolah dasar perlu menguasai literasi spasial. Namun, literasi spasial mahasiswa PGSD masih belum memuaskan. Salah satu upaya memperbaiki kualitas pembelajaran adalah dengan menerapkan model inkuiri berbantuan alat peraga edukatif. Penelitian ini bertujuan mengetahui apakah model inkuiri berbantuan alat peraga edukatif berpengaruh terhadap literasi spasial. Penelitian ini merupakan kuasi eksperimen dengan populasinya mahasiswa PGSD, Universitas PGRI Adi Buana Surabaya semester I tahun 2019/2020. Melalui purposive sampling, peneliti memilih kelas 2019 D sebagai kelas eksperimen dan kelas $2019 \mathrm{~F}$ sebagai kelas kontrol. Data diperoleh melalui metode tes dan dokumentasi. Analisis data menggunakan uji beda rerata. Hasil penelitian ini menunjukkan model inkuiri berbantuan alat peraga edukatif berpengaruh terhadap literasi spasial.
\end{abstract}

Kata kunci: alat peraga edukatif, inkuiri, literasi spasial

\begin{abstract}
Spatial literacy is related to the ability to use mathematics related to geometry. Prospective elementary school teachers need to master spatial literacy. However, the spatial literacy of PGSD students is still unsatisfactory. One of the lecturers' efforts to improve the quality of learning. An inquiry-assisted inquiry model of educational props can be an alternative. The purpose of this study is to determine whether the inquiry model assisted by educational teaching aids influences spatial literacy. This research is a quasi-experimental study with the population of semester I PGSD students in 2019/2020. Through purposive sampling, researchers chose class $D$ as the experimental class and class $F$ as the control class. Data obtained through the test method. Data analysis uses a mean different test. The results showed that there was an influence of the inquiry model assisted by educational teaching aids on spatial literacy.
\end{abstract}

Keywords: educational teaching aids, inquiry, spatial literacy

\section{Pendahuluan}

Pembelajaran matematika abad 21 mengharapkan mahasiswa untuk mampu berpikir kritis, kreatif, dan inovatif dalam menyelesaikan permasalahan dunia nyata. Keterampilan khusus yang dibutuhkan untuk menghadapi tantangan globalisasi adalah literasi matematika. Literasi matematika berperan dalam membentuk masyarakat yang siap tantangan dan menggunakan pengetahuan matematika dalam dunia nyata (Morgan \& Kett, 2003; Stacey, 2011; Fathani, 2016).

Berbicara tentang matematika, tentunya tidak terlepas dengan materi geometri. Seorang mahasiswa dituntut untuk mempunyai kemampuan menggunakan pengetahuannya untuk menyelesaikan masalah sesuai konteks personal maupun sosial terkait geometri. Kemampuan terkait menggunakan konten geometri disebut literasi spasial.

Literasi spasial didefiniskan sebagai keterampilan berpikir untuk mengomunikasikan ide-ide, menformulasikan situasi, dan permasalahan kehidupan nyata yang terkait dengan keruangan (Jablonka, 2003; De Lange, 2003; Tort dan Dort, 2015). Literasi spasial sangat dibutuhkan dalam kehidupan, tidak hanya terkait pendidikan 
Via Yustitia

namun bias dalam ilmu geografi Jarvis, Kraftl, \& Dickie (2017). Misalnya, penentuan lokasi tempat dan pembacaan peta. Literasi spasial termasuk salah satu domain dalam tes PISA bidang matematika.

Hasil PISA tahun 2018 menunjukkan siswa Indonesia di bidang matematika termasuk kategori rendah (OECD, 2019). Hasil observasi peneliti di PGSD Universitas PGRI Adi Buana Surabaya juga menunjukkan bahwa mahasiswa PGSD masih kesulitan ketika menyelesaikan masalah terkait geometri. Misalnya, mahasiswa sudah mengetahui rumus luas permukaan balok. Namun, saat diberi permasalahan terkait pengecatan dinding ruangan, ia tidak mampu menformulasikan model matematika untuk mencari solusi permasalahan tersebut. Penelitian pendahuluan yang dilakukan peneliti juga menunjukkan kemampuan literasi mahasiswa belum menunjukkan hasil yang memuaskan (Yustitia \& Juniarso, 2020).

Kesulitan mahasiswa terkait literasi spasial adalah kurang aktifnya mahasiswa terlibat dalam aktifitas penemuan konsep geometri. Mahasiswa juga tidak diberi kesempatan untuk memanfaatkan alat peraga edukatif yang dapat memvisualisasikan konsep geometri padahal tersedia di kampus. Hasil penelitian Riyanto,dkk (2014) menunjukkan bahwa pemanfaatan alat peraga edukatif dapat efektif terhadap kemampuan pemecahan masalah soal setara PISA.

Menghadapi permasalahan yang terjadi, seorang dosen perlu melakukan inovasi pembelajaran sebagai upaya perbaikan prestasi mahasiswanya (Fanny, 2019). Dosen perlu memperhatikan model pembelajaran dan media edukatif yang dapat diimplimentasikan untuk meningkatkan literasi spasial mahasiswa. Salah satu model pembelajaran yang dapat digunakan sebagai alternatif adalah model inkuiri. Model iknkuiri dapat melatih kemampuan berpikir kritis mahasiswa (Wardani \& Yustitia, 2017).

Selain pemilihan model pembelajaran, diperlukan juga pemilihan media yang dapat digunakan untuk mempermudah kemampuan pemahaman konsep dan pemecahan masalah geometri. Alat peraga edukatif dapat dimanfaatkan untuk mendukung literasi spasial mahasiswa.

Dosen dapat memanfaatkan alat peraga edukatif yang tersedia di Laboratorium Matematika dan IPA. Hasil penelitian Sudarwanto \& Hadi (2014) menunjukkan bahwa penggunaan alat peraga edukatif dapat memberikan pengaruh positif terhadap kemampuan berpikir kritis siswa sekolah dasar pada materi geometri.

Berdasarkan pemaparan di atas, peneliti mengadakan studi penelitian yang bertujuan mengetahui pengaruh model inkuiri berbantuan alat peraga edukatif terhadap literasi spasial mahasiswa PGSD Universitas PGRI Adi Buana Surabaya.

\section{Metode Penelitian}

Penelitian ini merupakan penelitian kuantitatif, jenis kuasi eksperimental. Penelti menggunakan desain posttest only control grup design. Penelitian ini dilaksanakan di Prodi PGSD, Fakultas Keguruan dan IImu Pendidikan, Universitas PGRI Adi Buana. Popolasinya adalah mahasiswa PGSD semester I tahun 2019/ 2020 berjumlah 280 orang. Melalui purposif sampling, terpilih kelas 2019 D sebagai kelas eksperimen dan kelas 2019 F sebagai kelas kontrol.

Data diperoleh melalui metode tes. Peneliti menggunakan lima soal literasi spasial yang berbentuk uraian. Soal diadopsi dari soal PISA 2015. Soal berbentuk uraian dengan konten geometri. Konteks soal berupa pribadi, sosial, dan pekerjaan. Analisis data menggunakan uji beda rerata. Sebelumnya, peneliti melakukan uji prasyarat (uji normalitas dan uji homogenitas). Data dianalisis menggunakan bantuan SPSS versi 22 .

\section{Hasil dan Pembahasan}

Tabel 1 berikut menyajikan deskripsi hasil posttest literasi spasial kelas eksperimen dan kelas kontrol. 
Tabel 1. Deskripsi Hasil Posttest

\begin{tabular}{|l|r|r|r|r|r|}
\hline & \multicolumn{1}{|c|}{} & Minimum & Maximum & \multicolumn{1}{c|}{ Mean } & $\begin{array}{c}\text { Std. } \\
\text { Deviation }\end{array}$ \\
\hline kelas.eks & 35 & 67.00 & 90.00 & 80.3714 & 6.11212 \\
kelas.kontrol & 35 & 56.00 & 95.00 & 73.5714 & 7.94572 \\
Valid N & 35 & & & & \\
(listwise) & & & & & \\
\hline
\end{tabular}

Berdasarkan tabel 1 diketahui bahwa rata-rata literasi spasial kelas eksperimen sebesar 80.37 dan rata-rata literasi spasial kelas kontrol sebesar $73.57 \mathrm{Hal}$ ini berarti secara deskriptif terdapat perbedaan ratarata kelas eksperimen dan kelas kontrol.
Sebelum dilakukan uji perbedaan dua rata-rata, perlu dilakukan uji normalitas untuk mengetahui apakah kedua populasi berasal dari data berdistribusi normal atau tidak. Berikut hasil uji normalitas posttest kelas eksperimen dan kelas kontrol.

Tabel 2. Hasil Uji Normalitas Posttest

\begin{tabular}{|l|r|r|r|r|r|r|}
\hline \multirow{2}{*}{} & \multicolumn{2}{|c|}{ Kolmogorov-Smirnov ${ }^{\circledR}$} & \multicolumn{3}{|c|}{ Shapiro-Wilk } \\
\cline { 2 - 7 } & \multicolumn{1}{|c|}{ Statistic } & \multicolumn{1}{c|}{ df } & Sig. & Statistic & \multicolumn{1}{c|}{ df } & \multicolumn{1}{c|}{ Sig. } \\
\hline kelas.eks & .153 & 35 & .038 & .948 & 35 & .096 \\
kelas kontrol & .095 & 35 & $200^{*}$ & .974 & 35 & 575 \\
\hline
\end{tabular}

Berdasarkan hasil tabel 2 di atas menunjukkan bahwa signifikansi kelas eksperimen dan kelas kontrol lebih besar dari 0.05 , artinya kedua kelas berasal dari populasi yang berdistribusi normal.

\section{Tabel 3. Hasil Uji Perbedaan Rerata Posttest}

\begin{tabular}{|c|c|c|c|c|c|c|c|c|}
\hline & \multicolumn{5}{|c|}{ Paired Differences } & \multirow[t]{3}{*}{$\mathrm{t}$} & \multirow[t]{3}{*}{ df } & \multirow[t]{3}{*}{$\begin{array}{c}\text { Sig } \\
\text { (2- } \\
\text { tail } \\
\text { ed) }\end{array}$} \\
\hline & \multirow{2}{*}{$\begin{array}{l}\text { Me } \\
\text { an }\end{array}$} & \multirow{2}{*}{$\begin{array}{l}\text { Std. } \\
\text { Devia } \\
\text { tion }\end{array}$} & \multirow{2}{*}{$\begin{array}{l}\text { Std. } \\
\text { Error } \\
\text { Mean }\end{array}$} & \multicolumn{2}{|c|}{$\begin{array}{c}95 \% \text { Confidence } \\
\text { Interval of the } \\
\text { Difference }\end{array}$} & & & \\
\hline & & & & Lower & Upper & & & \\
\hline $\begin{array}{ll}\text { Pair 1 } & \text { kelas.e } \\
& \text { ks - } \\
& \text { kelas.k } \\
& \text { ontrol }\end{array}$ & $\begin{array}{r}6.80 \\
000\end{array}$ & $\begin{array}{l}11.09 \\
796\end{array}$ & 1.87590 & 2.98772 & 10.61228 & 3.625 & 34 & .001 \\
\hline
\end{tabular}

Tabel 3 di atas diperoleh perbedaan mean sebesar 6.8 yang berarti selisih skor hasil literasi spasial kelas eksperimen dan kelas kontrol. Harga positif bermakna setelah diberi perlakuan menggunakan model inkuiri lebih baik daripada pembelajaran klasikal. Selanjutnya pada tabel ini juga diperoleh standar error mean adalah 1.87 yang menunjukan angka kesalahan baku perbedaan rata-rata. Hasil terpenting dari tabel ini adalah harga statistik $t=3.625$ dengan df 34 dan angka signifikan 0.001. Atau p-value 0,000 $<0,05$. Dengan demikian dapat disimpulkan bahwa terdapat perbedaan hasil yang signifikan antara literasi spasial kelas eksperimen dan kelas kontrol. 
Via Yustitia

Hasil penelitian menunjukkan bahwa model inkuiri berbantuan alat peraga edukatif berpengaruh terhadap literasi spasial mahasiswa PGSD. Hasil penelitian Sutama dkk (2014) dan Nasution (2018) menyatakan bahwa model inkuiri meningkatkan kemampuan berpikir kritis dan keterampilan siswa. Melalui inkuiri, mahasiswa lebih siap dalam proses kognitif. Mahasiswa juga lebih semangat dan termotivasi dalam belajar geometri, serta menggunakan pengetahuan yang dimilikinya untuk menyelesaikan masalah. Selain itu, Binangun \& Hakim (2016), Hikmah (2016), dan Sayfuddin (2020) menyatakan bahwa alat peraga edukatif berpengaruh terhadap prestasi belajar matematika siswa.

Penggunaan alat peraga edukatif membantu mahasiswa memahami konsep geometri sederhana. Misalnya, luas permukaan bangun ruang sisi datar yang diperoleh melalui konsep luas bangun datar. Melalui pemahaman konsep yang mantap, mahasiswa mampu mengaplikasi konsep luas bangun datar untuk menyelesaikan permasalahan yang terkait konteks sosial. Misalnya, jika mahasiswa ingin membuat sebuah almari kayu berbentuk balok. la dapat mengetahui ukuran kayu yang dapat dibutuhkan untuk membuat sebuah almari. Saat ia akan mengecat permukaan almari tersebut, ia mampu memperkirakan jumlah cat yang dibutuhkan untuk melapisi almari tersebut. Hal ini sejalan dengan hasil penelitian Syaifudin (2020) bahwa penggunaan alat peraga edukatif mampu meningkatkan kemampuan pemecahan masalah siswa sekolah dasar.

Penerapan model inkuiri berbantuan alat peraga edukatif dapat membuat mahasiswa untuk kritis, kreatif, dan inovatif sehingga pengetahuan geometri yang didapatkan dari proses pembelajaran dapat diterapkan dengan baik. Literasi spasial mahasiswa yang diajar dengan model inkuiri berbantuan alat peraga edukatif lebih baik daripada literasi spasial mahasiswa yang diajar menggunakan model klasikal tanpa alat peraga edukatif. Hal tersebut sejalan dengan hasil penelitian Purwasih (2015) dan Hendracipta (2017) yang menyatakan bahwa model inkuiri memberikan hasil yang baik daripada model konvensional.

\section{Kesimpulan}

Model inkuiri berbantuan alat peraga edukatif berpengaruh terhadap literasi spasial. Oleh karena itu, model inkuiri dapat digunakan sebagai alternatif untuk meningkatkan literasi spasial. Untuk mempermudah penyampaian materi geometri yang bersifat abstrak, alat peraga edukatif juga perlu dimanfaatkan.

\section{Daftar Pustaka}

Binangun, H. H., \& Hakim, A. R. (2016). Pengaruh penggunaan alat peraga jam sudut terhadap hasil belajar matematika. JKPM (Jurnal Kajian Pendidikan Matematika), 1(2), 204-214.

De Lange, J. (2003). Mathematics for literacy. Quantitative literacy: Why numeracy matters for schools and colleges, 80, 75-89.

Fanny, A. M. (2019, March). Analysis Of Pedagogical Skills And Readiness Of Elementary School Teachers In Support Of The Implementation Of The 2013 Curriculum. In International Conference on Bussiness Law and Pedagogy (Vol. 1, No. 1, pp. 5963). 
Fathani, A. H. (2016). Pengembangan literasi matematika sekolah dalam perspektif multiple intelligences. Edu Sains: Jurnal Pendidikan Sains dan Matematika, 4(2).

Hendracipta, N., Nulhakim, L., \& Agustini, S. M. (2017). Perbedaan Kemampuan Berpikir Kritis Siswa Melalui Penerapan Model Inkuiri Terbimbing di Sekolah Dasar. JPsd (Jurnal Pendidikan Sekolah Dasar), 3(2), 215-227.

Hikmah, N. (2016). Peningkatan hasil belajar matematika tentang penjumlahan dan pengurangan bilangan bulat melalui alat peraga mistar bilangan pada siswa kelas iv SDN 005 Samarinda Ulu. PENDAS MAHAKAM: Jurnal Pendidikan Dasar, 1(1), 80-85.

Jablonka, E. (2003). Mathematical Literacy. Second International Handbook of Mathematics Education, 1999(Oecd), 75-102. https://doi.org/10.1007/978-94010-0273-8_4

Jarvis, C. H., Kraftl, P., \& Dickie, J. (2017). (Re)Connecting spatial literacy with children's geographies: GPS, Google Earth and children's everyday lives. Geoforum, 81, 2231. https://doi.org/10.1016/j.geoforum.2017.02.006

Morgan, M., \& Kett, M. (2003). The prison adult literacy survey. Results and implications. Nasution, S. W. R. (2018). Penerapan Model Inkuiri Terbimbing (Guided Inquiry) dalam Meningkatkan Kemampuan Berpikir Kritis pada Pembelajaran Fisika. Jurnal Education and Development, 3(1), 1-1.

OECD. (2019). PISA 2018 Assessment and Analytical Framework. In OECD Report. https:/ /doi.org/10.1787/9789264190511-en

Purwasih, R. (2015). Peningkatan Kemampuan Pemahaman Matematis dan Self Confidence Siswa MTS di Kota Cimahi Melalui Model Pembelajaran Inkuiri Terbimbing. Didaktik, 9(1), 16-25.

Riyanto, R., Wardono, W., \& Wijayanti, K. (2014). Keefektifan PMRI Berbantuan Alat Peraga Terhadap Kemampuan Pemecahan Masalah Serupa PISA Pada Kelas VII. Kreano, Jurnal Matematika Kreatif-Inovatif, 5(1), 33-40.

Sutama, I. N., Arnyana, I. B. P., Si, M., Swasta, I. B. J., \& Si, M. (2014). Pengaruh model pembelajaran inkuiri terhadap ketrampilan berpikir kritis dan ketrampilan proses sains pada pelajaran biologi Kelas XI IPA SMA Negeri 2 Amlapura. Jurnal Pendidikan dan Pembelajaran IPA Indonesia, 4(1).

Sayfuddin, A. (2020). Pengaruh Pendekatan Pendidikan Matematika Realistik Indonesia (PMRI) Berbantu Alat Peraga Edukatif Terhadap Pemecahan Masalah Matematika Di Kelas IV Sdn 14 Way Serdang Mesuji (Doctoral dissertation, UIN Raden Intan Lampung).

Stacey, K. (2011). The PISA view of mathematical literacy in Indonesia. Journal on Mathematics Education, 2(2), 95-126. 
Via Yustitia

Sudarwanto, S., \& Hadi, I. (2014). Pengembangan Alat Peraga Pembelajaran Matematika Sekolah Dasar untuk Meningkatkan Kemampuan Berpikir Matematis Siswa. Sarwahita, 11(1), 32-37.

Tort, F., \& Drot-Delange, B. (2015, September). Visual literacy in introductory informatics problems. In International Conference on Informatics in Schools: Situation, Evolution, and Perspectives (pp. 175-182). Springer, Cham.

Wardani, I. S., \& Yustitia, V. (2017). Penerapan Model Pembelajaran Inkuiri Untuk Melatih Kemampuan Berpikir Kritis Mahasiswa Pgsd Unipa Surabaya. Pendas/ : Jurnal IImiah Pendidikan Dasar, II.

Yustitia, Via., \& Juniarso, T. (2020). Literasi Matematika Mahasiswa Dengan Gaya Belajar Visual. Malih Peddas (Majalah IImiah Pendidikan Dasar), 9(2), 100-109. 